\title{
O CRIME DE DESACATO E SUA CORRELAÇÃO COM A ATITUDE REPRESSIVA ESTATAL
}

\section{Laura Garbini Both ${ }^{1}$}

Ane Elise Brandalise Gonçalves²

\begin{abstract}
Resumo
O presente artigo tem como propósito o estudo do crime de desacato e qual seria sua relação com a atitude repressiva, "policialesca", existente no Estado, celeuma dos períodos autoritários e ditatoriais vivenciados no Brasil e no seu entorno. Mais além, propugna este trabalho pela inconstitucionalidade do tipo penal do desacato no Brasil e seus fundamentos. $O$ problema da pesquisa consiste em compreender o crime de desacato no Brasil e no seu entorno, realizando uma análise de conjuntura que leve em conta os fatores políticos e jurídicos. Em um segundo momento, procura-se explicitar a posição da inconstitucionalidade do crime de desacato no Brasil, tentando elucidar os principais fundamentos sob os quais se assenta esta posição. A hipótese ora apresentada é de que o crime de desacato é fruto de um Estado que preza não pelo seu povo, mas pela própria autoridade. Em outras palavras: é o desacato uma das celeumas dos períodos ditatoriais e da imposição de um Estado que está acima do povo e não vice-versa. Atualmente, à luz de um novo sistema constitucional há de se falar em inconstitucionalidade deste tipo penal, todavia, tal posicionamento ainda propõe alguns desafios. A justificativa centra-se no fato de que a legislação penal faz repensar que determinadas atitudes são em prol, em benefício, do Estado e não do povo. Assim, cabível o estudo do crime de desacato (especialmente no Brasil) e a realização de uma análise do porvir, isto é, na realização de uma análise de conjuntura. Por fim, o artigo possui uma metodologia teórico-dedutiva, na qual se valeu, como instrumento metodológico, da análise de conjuntura e de cenários.
\end{abstract}

Palavras-chave: Desacato; Sistema Constitucional; Sistema Interamericano de Proteção aos Direitos Humanos.

\section{INTRODUÇÃO}

O presente artigo visa ao estudo do crime de desacato na América Latina, sobretudo na legislação penal brasileira (Código Penal, artigo 331), e qual seria sua relação com a atitude repressiva (pode-se dizer também "policialesca") existente no Estado, celeuma dos períodos autoritários e ditatoriais vivenciados por esta região. Para tanto, em um primeiro momento será feita uma análise histórico-jurídica do crime, seus fundamentos e as atitudes tomadas pelo Poder Judiciário em conjunto com polícia. Ver-se-á primeiramente o desacato no Brasil e, após, com base nas análises feitas pela Comissão Interamericana de Direitos Humanos, ver-se-á casos ocorridos

\footnotetext{
${ }^{1}$ Doutora em Educação pela Pontifícia Universidade Católica do Paraná - PUCPR. Professora de Sociologia e Antropologia na UNIBRASIL em Curitiba/PR. E-mail: laura.both@unibrasil.com.br

${ }^{2}$ Mestranda em Direitos Fundamentais e Democracia no Centro Universitário Autônomo do Brasil - UNIBRASIL (2015) e pesquisadora do Grupo PATRIAS. E-mail: anebrand@gmail.com
} 
na América Latina (com destaque para o estudo sobre a Argentina e o Chile). Procurou-se, pois, a partir dos critérios jurídico e político, realizar uma análise de conjuntura. Mais precisamente, no plano político, constata-se que se por um lado as legislações penais que criminalizaram o desacato seriam de cunho liberal (que defende direitos fundamentais básicos como o de igualdade e de liberdade), por outro lado, de modo perverso, institucionalmente reconhece e incentiva uma relação verticalizada entre Estado e sociedade civil, na qual não há igualdade, mas há submissão, o que gera um contrassenso, uma dificuldade lógica.

Após, com a clarificação que hoje se vive em um momento diferente daquilo que se vivia à época dos regimes autoritários, passa-se ao estudo dos fundamentos que baseiam o entendimento pela inconstitucionalidade do crime de desacato. Não obstante, ainda nos dias atuais são vários os casos de desacato que chegam à mesa do Poder Judiciário, o que ainda faz questionar sobre a relação entre Estado e indivíduo, situação tal que deve ser superada para enfrentar os desafios que o novo sistema constitucional impõe. Por isso mesmo, muito mais que apenas observar os fatos e acontecimentos, busca o presente artigo instigar o leitor a se questionar sobre a forma como o Estado se porta e se tal forma pode vir a mudar ou não, sendo que o atual sistema constitucional, tanto no Brasil quanto em seu entorno, pressupóe que ocorra este debate acerca do desacato.

Ao longo de todo trabalho remanesce a seguinte pergunta: "se o desacato constituir-se-ia uma divergência de todo um novo sistema, até quando continuará a ser aplicado? ”. É justamente tal questão que procurar-se-á desvendar ao fim, valendo-se como instrumento metodológico a análise de conjuntura e de cenários para poder responder a questão.

A metodologia usada ao longo do artigo foi teórico-dedutiva, com o uso de alguns exemplos práticos que ficaram reconhecidos no palco internacional e destaque para o uso de documentos do sistema interamericano de direitos humanos.

\section{O CRIME DE DESACATO NO BRASIL E NO SEU ENTORNO: REFLEXO DE ATITUDES "POLICIALESCAS" ESTATAIS.}

Para compreensão do crime de desacato é preciso observar a conjuntura vivida e realizar a sua correlação com os dias atuais, a partir de alguns critérios. Escolheu-se aqui o estudo a partir de uma perspectiva constitucional e sua ligação e convergências/divergências com a legislação penal do desacato (tão comum na América Latina).

Pretende-se, pois, verificar, ainda que de maneira superficial, a legislação penal, as relações de poder e atores envolvidos no palco analisado e os fatos portadores de futuro nos países a serem ora analisados. Tem-se aqui, pois, uma realização da análise de conjuntura e de cenários, o que a priori pode parecer um contrassenso, uma vez que tal instrumento metodológico, especialmente no que tange aos cenários, deita raízes no 
planejamento militar estratégico do período do pós-guerras (SCHWARTZ, 1996, p. 206), entretanto adequa-se ao trabalho, até mesmo porque este não visa ao combate do Exército ou da Polícia em si mesma (seja qual for: Polícia Militar, Polícia Civil ou Polícia Municipal), bem como não visa adentrar no âmago da questão da militarização da segurança pública da América Latina. Combate-se aqui à atitude "policialesca” e violenta, que é diversa da atitude policial em consonância com todo novo sistema constitucional democrático.

A conjuntura, entretanto, desde já se adiante, é clara ao demonstrar que os Estados da América Latina, ao menos em sua maioria, adotaram um modelo de polícia arquitetado à defesa do Estado, e não da população. Isso fica ainda mais claro quando no estudo dos períodos de ditaduras militares vivenciados (a exemplo, cite-se da Argentina, Brasil, Chile e Uruguai), em que os Estados se valeram da legislação penal e da Polícia para alcançar seus fins, mediante os fundamentos de ordem pública, de honra funcional e de prevalência da autoridade estatal sobre o interesse particular.

Uma dessas formas de repressão contidas na legislação penal se dá por meio do enquadramento do fato no tipo penal de desacato. Longe de adentrar nas raízes históricas mais profundas dessa figura jurídica, cabe apenas anotar que o desacato não é aplicado apenas à proteção da atividade policial ou dos policiais, mas sim a toda e qualquer figura estatal, sendo que em seus primórdios correlaciona-se à proteção do Juiz, como autoridade do poder (PRADO, 2010, p. 515):

A punição ao crime de desacato teve origem no Direito antigo, inclusive no Direito romano, quando se reprimiam as injúrias perpetradas contra magistrados no exercício e suas funções como injurias agravadas. Assim, a injúria perpetrada contra magistrado era classificada de iniuria atrox, sujeitando o agente a pena capital, quando pertencente a classe dos humilatores.

$\mathrm{Na}$ Idade Média, os práticos mantiveram esse ensinamento, passando a ofensa direcionada a sacerdote também a ser considerada como iniuria atrox. Verifica-se, ainda, que surgiu entre os práticos a controvérsia sobre se a tutela penal deveria recair também sobre o delito perpetrado contra magistrado que não estivesse no exercício das suas funções e na hipótese de que as ofensas não tivessem relação com o exercício funcional.

A evolução do instituto foi sentida no Código francês de 1820, quando a ofensa direcionada a certas categorias de funcionários passou a ser classificada como crime autônomo, com o nomen juris de outrage, no que foi seguido pelo Direito italiano, em que a figura passou a ser conhecida por oltraggio.

No aspecto político é de se ressaltar que as legislações penais da América Latina que criminalizavam o desacato eram todas de cunho liberal/neoliberal, fruto de toda esta bagagem européia ora explicitada. Nesta perspectiva tem-se que se por um lado o liberalismo pregava direitos fundamentais básicos como a liberdade e a igualdade - a qual pressupunha, por certo, um afastamento do Estado sobre a atividade do particular, da sociedade civil, só atuando quando estritamente necessário - por outro lado, de modo perverso, acabou por reconhecer e alimentar a ideia de um estado de legalidade e de uma relação verticalizada entre Estado e sociedade civil ou entre Polícia e cidadão, relações nas quais, por certo, não havia igualdade e havia a interferência estatal de modo repressivo, o que, por certo, gera uma dificuldade lógica de compreensão, ainda mais nos dias atuais, em que se 
vive, não apenas no Brasil, mas em toda região, num novo sistema constitucional em que não mais basta a lei, mas deve ela estar vinculada ao respeito para com os direitos fundamentais e para com a democracia (tarefa tal que deve superar os problemas gerados pelo liberalismo clássico).

No Brasil o desacato está descrito no artigo 331 do Código Penal Brasileiro de 1940, época, portanto, anterior à Ditadura Militar, mas não menos autoritária (vigorava, então, o regime ditatorial de Vargas), sendo que tal Código e tal artigo continuam vigentes, tendo passados pelo regime militar e pela repressão dos anos 1960.

No ponto, não se quer afirmar aqui que o período ditatorial que marcou o advento do Código Penal de 1940 seja o pior momento na história brasileira, muito pelo contrário. Em realidade, verifica-se que o delito de desacato já existia anteriormente na antiga lei penal, deitando raízes nas Ordenações Filipinas, à época com forte influência no Direito Romano (PRADO, 2010, p. 515). Contudo, se da leitura de toda legislação penal brasileira verifica-se que se antes o desacato era voltado à proteção do magistrado e de seus funcionários, o Código Penal de 1940 abrangeu o leque de proteção a todo funcionário público em exercício (ou em razão de seu ofício), com um tipo penal aberto, apto a possibilitar a penalização de uma série de condutas.

Com efeito, segundo o artigo 331 do Código Penal Brasileiro, constitui crime "desacatar funcionário público no exercício ou em razão dela", cuja pena é de detenção, de seis meses a dois anos, ou multa, e está inserido no rol de "crimes praticados por particular contra a administração em geral". A criminalização desta conduta encontra sua razão na necessidade de proteção da honra funcional (a qual seria o que se fala, na seara do Direito, de "bem jurídico tutelado"). Em outras palavras, conforme a doutrina: "a honra do funcionário é tutelada, mercê do desacato, de modo muito mais rigoroso do que a honra do particular. Tal se dá porque o funcionário é portador de um interesse público, desempenhando posto de particular relevo no ordenamento do Estado" (PAGLIARO, DA COSTAJÚNIOR, 1999, p. 205).

O Código Penal, no entanto, não descreve quais condutas e formas poderiam ser enquadradas como "desacatar", e nem assim teria êxito, pois existe uma variedade de palavras que podem traduzir, no contexto colocado, em ultraje. Assim, citem-se como exemplos as seguintes situações veiculadas na mídiaª : (a) "Ao defender sobrinho flagrado com cocaína mulher é presa por desacato"; (b) "Jovem é detido depois de 'dar o dedo' para delegado de polícia"; (c) "Mãe de infrator ofende e bate em policial militar na delegacia”, (d) "Confusão entre gerente de banco e delegado termina na delegacia", (e) "Jovem critica trabalho da polícia e delegado registra B.O contra ele no PI", (f) "Prefeito joga 'maizena' em tenente e acaba preso", (g) "Major da PM é preso por desacatar Delegado",etc.

\footnotetext{
${ }^{3}$ Notícias retiradas do site Portal Nacional dos Delegados (Disponível em: <http://delegados.com.br/>. Acesso em: 03 jun 2015), datadas recentemente, de 2012 até 2015. A escolha de tal site, para ilustrar a situação do desacato, não se deu por acaso. Foi proposital colher tais notícias de um site que defende justamente a criminalização da conduta de desacatar e formas de maior proteção dos policiais.
} 
Neste ponto, o problema, ao menos na esfera dos Direitos Fundamentais, é que isso pode gerar impedimentos a exercícios de direitos fundamentais, a exemplo maior do direito à liberdade de expressão e de sua faceta na opinião pública e na antítese dos projetos políticos apresentados, além da criminalização da conduta como desacato poder arrefecer as possibilidades de diálogo da população com o Governo. Tem-se, pois, uma incerteza que põe à prova o domínio estatal sobre a sociedade civil. Neste sentido, reconheceu o próprio Ministro do STJ, Gilson Dipp, que "da maneira como está hoje, nunca se sabe bem se é crime de desacato ou manifestação de insatisfação" (STJ, 2012).

Ademais, o desacato, apesar de não ser figura adstrita aos policiais, como visto antes, faz questionar a instituição policial da sociedade e sua correlação com o Poder Judiciário, responsável por analisar e julgar os infratores. No ponto, Antônio Candido, através da análise da repressão, feita nos idos dos anos 70, época da Ditadura Militar Brasileira, verifica por meio da literatura e do cinema que a atividade policial, em conjunto com o Poder Judiciário, passa a utilizar da legislação penal para consolidar um Estado que estaria acima do povo, via intimidação do indivíduo. Assim, acerca da correlação entre Polícia e Justiça (CANDIDO, 1972, p. 02, grifos nossos):

“(...) foi Kafka, n' $O$ Processo, quem viu o aspecto por assim dizer essencial e ao mesmo tempo profundamente social. Viu a polícia como algo inseparável da justiça, e esta assumindo cada vez mais um aspecto de polícia. Viu de que maneira a função de reprimir (mostrada por Balzac como função normal da sociedade) adquire um sentido transcendente, ao ponto de acabar se tornando a sua própria finalidade. Quando isso ocorre, ela desvenda aspectos básicos do homem, repressor e reprimido

Para entrar em funcionamento, a polícia-justiça de Kafka não tem necessidade de motivos, mas apenas de estímulos. E uma vez em funcionamento não pode mais parar, porque sua finalidade é ela própria. Para isso, não hesita em tirar qualquer homem do seu trilho até liquidá-lo de todo, física ou moralmente. Não hesita em pô-lo (seja por que meio for) à margem de ação que o Estado quer reprimir, sem se importar se o indivíduo visado está envolvido nela. Em face da importância ganha pelo processo punitivo (que acaba tendo o alvo espúrio de funcionar, pura e simplesmente, mesmo sem motivo), a materialidade da culpa perde sentido"

Não é preciso racionalizar muito para perceber que um Código Penal em prol da "autoridade estatal" e com uma instituição policial bastante repressiva vai ao encontro das ideias do último período ditatorial militar vivido pelo Brasil (1964 - 1985), a qual passa pela lei a ter o aval desde a adequação do fato para desacato até a prática de detenção arbitrária, torturas, etc. Como consequência, até hoje tramitam casos no sistema interamericano de direitos humanos envolvendo violações de direitos durante o regime militar e, também, casos envolvendo a violência policial (estes não apenas adstritos à época da Ditadura Militar, mas também ocorridos até os dias atuais). Assim foi a constatação, por exemplo, da jurista Flávia Piovesan, segundo a qual de 98 casos estudados contra o Estado Brasileiro, que foram admitidos de 1970 a 2008, 38 deles corresponderiam a situações de violência policial (PIOVESAN, 2010, p. 327).

Outrossim, de maneira mais severa e punida com maior rigor, o desacato também está presente na esfera 
castrense, por meio do Código Penal Militar, o Decreto-lei no 1.001/69, que também surge pari passu à período ditatorial brasileiro. Nesse sentido, lembra Zaffaroni que não apenas no Brasil mas como em toda América Latina há presente duas facetas do mesmo Estado: a do Estado de Polícia e, por outro lado, a do Estado de Direito, de atuação simultânea em todo o Sistema penal (ZAFFARONI, 2011, p. 95). Mais especificamente, se pode encontrar a figura do desacato na esfera penal militar nos artigos 298, 299 e 300, bem como no artigo 341.

Ainda assim, sem deixar de reconhecer que o desacato também precisa ser discutido na esfera militar, em que pese com base em diferentes fundamentos, o foco do presente trabalho é o estudo do desacato na esfera penal comum.

Infelizmente, por mais que a legislação penal tenha sido usada como auxílio da Ditadura Militar, ainda com o advento de um novo sistema constitucional brasileiro, democrático e aberto, crimes como o desacato permanecem no Código Penal, sob os mesmos argumentos (da honra funcional, do prestígio da Administração Pública, da autoridade estatal, etc.).

Afora o Brasil, outros 16 países da América Latina, como Argentina, Bolívia, Chile, Costa Rica, Uruguai e Venezuela contam (ou contavam) com a previsão do desacato em suas legislações penais, conforme Relatório da Comissão Interamericana de Direitos Humanos, já datado de tempos (OEA, 1999). E dentre as variadas situações circunscritas em torno do desacato, emblemáticos os casos que chegaram à esfera regional de proteção aos Direitos Humanos, como o caso da Argentina (versando, mais especificamente, sobre um jornalista, Horácio Verbistiky, que ao chamar uma autoridade estatal de "asqueroso", foi acusado por desacato), a qual, por força do posicionamento da Comissão Interamericana, acabou por extinguir de seu ordenamento jurídico o crime de desacato em 1993.

Outro país que ganhou os olhos da Comissão Interamericana por conta de uma série de ocorrências e, inclusive, chegou à Corte Interamericana foi o Chile, por meio do Caso Palamara, sendo que o país foi condenado em 2005 por este Tribunal Internacional, dentre outras medidas, a "tomar todas as medidas necessárias para anular e alterar, num prazo razoável, quaisquer disposições nacionais que são incompatíveis com as normas internacionais sobre a liberdade de pensamento e expressão" (CORTE IDH, 2005, p. 102). O caso Palamara versava, em resumo, sobre a proibição de publicação do livro de Humberto Antonio Palamara-Iribarne, em que se abordou questões relacionada com a inteligência militar e a necessidade de assegurar a sua conformidade com determinados padrões éticos, datado de 1993. Palamara, aposentado da Marinha chilena, teria sido processado por dois crimes de desobediência e, após condenado, ao convocar uma conferência da imprensa, foi novamente processado e condenado, desta vez por desacato. No caso, para além do desacato, também se discutia a (im)possibilidade da Justiça Militar julgar e condenar civis, tema tal que é questionado igualmente no Brasil e que pode ser correlacionado à atitudes policialescas tomadas pelo Estado contra o povo. 
Além dos casos da Argentina e Chile, fatos envolvendo países como Costa Rica, Panamá, Peru, Venezuela, entre outros, também estariam sob análise do sistema regional de proteção aos direitos humanos. Inclusive, casos brasileiros estariam sob o olhar deste sistema. No último Informe de la Relatoría Especial para la Libertad de Expresión, publicado em 2014, a Comissão citou o caso do repórter Bruno Amorim, detido, em 11 de abril de 2014, por fotografar ação da PM em desocupação da favela no RJ. Segundo consta, Amorim foi processado por desacato, incitação à violência e resistência. Também foi citada neste Informe Anual a tipificação por desacato de fatos envolvendo protestos contra a copa do mundo (OEA, 2015, p. 87). Na mesma oportunidade, a Comissão Interamericana ressaltou, mais uma vez, a necessidade dos países da América Latina em retirarem de seus ordenamentos jurídicos o crime de desacato (Ibidem, idem).

Mais recentemente, a defensoria pública do estado de São Paulo já protocolizou petição na Comissão Interamericana de Direitos Humanos, pedindo o fim da criminalização do desacato, com base na defesa de um metalúrgico que ao ter sido flagrado com drogas e detido teria chamado o agente policial de "policial semvergonha, corrupto, ladrão e vagabundo, não ficarei detido para sempre, você vai se ferrar, vai morrer", ao que, para além do crime de tráfico, teria respondido pelo crime de desacato (DEFENSORIA PÚBLICA DO ESTADO DE SÃO PAULO, 2014, p. 04).

Com efeito, fatos portadores de futuro já parecem demonstrar que a questão vem sendo modificada, de maneira gradual, sendo que, por certo, só se pode esperar atitudes diferentes a partir do momento em que haja um posicionamento e uma conscientização de que "o Estado foi originalmente concebido para a realização do bem comum, e que existe para o ser humano, e não vice-versa" (TRINDADE, 2006, p. 17), buscando extirpar a cultura "policialesca" existente no Estado e imposta à sociedade civil, para se adequar ao novo sistema constitucional, o qual pressupõe, por certo, não um autoritarismo estatal.

É com base neste novo sistema constitucional, ainda em construção na América Latina e no Brasil, que se defende pela inconstitucionalidade do crime de desacato e pela necessidade de repensar todo discurso institucional que foi imposto à sociedade civil. É o que o capítulo seguinte irá desnudar, analisando os fundamentos existentes na defesa pela inconstitucionalidade do desacato e constatando os fatos portadores de futuro, que podem dar luz a direcionamentos nos próximos anos.

\section{A INCONSTITUCIONALIDADE DO DESACATO A LUZ DO NOVO SISTEMA CONSTITUCIONAL}

Como visto, o Brasil passou por variados períodos ditatoriais, sendo que no advento do Código Penal, em 1940, vivia-se a era ditatorial de Getúlio Vargas. De 1964 a 1985 viveu-se no Brasil um período de ditadura militar, marcado pela repressão e autoritarismo, em grande parte ilustrada pela atividade policial e do Poder 
Judiciário.

No ponto, reitere-se aqui não se quer afirmar aqui que o período ditatorial que marcou o advento do Código Penal de 1940 seja o pior momento na história brasileira, muito pelo contrário. Em realidade, verifica-se que o delito de desacato já existia anteriormente na antiga lei penal, deitando raízes nas Ordenações Filipinas, à época com forte influência no Direito Romano (PRADO, 2010, p. 515).

De todo modo, de 1985 em diante procurou-se não somente o estabelecimento de uma nova ordem constitucional, mas, sim, da construção de todo um novo sistema constitucional, democrático e mais aberto, tendo como pressuposto, notadamente em sua Constituição de 1988, "o imperativo categórico Kantiano de que o ser humano é um fim em si mesmo e jamais simples meio (mero objeto)" (SARLET et alii, 2012, p. 378).

Fato este não somente brasileiro, mas que ocorre em nível regional e, em certa análise, também global, esse novo sistema constitucional, em constante construção, impõe uma superação das celeumas dos períodos ditatoriais anteriores, a exemplo maior, no caso, da figura do desacato.

E é justamente em face deste novo sistema constitucional que se comenta sobre a inconstitucionalidade do crime de desacato. Assim, brevemente passa-se a observar os fundamentos que sustentam esta posição e, após, uma análise de cenários, para verificar se em um futuro próximo será possível se afirmar que o desacato deixará de ser crime ou não.

\section{Fundamentos da inconstitucionalidade do desacato}

De forma simplificada, constata-se que, ao menos até o presente momento, alguns fundamentos principais pela defesa da inconstitucionalidade do crime de desacato, conforme passa-se a verificar. Observe-se aqui que se toma o Direito Penal e toda sua legislação de forma conglobante (conforme expressão célebre de Zaffaroni) e, principalmente, numa visão constitucionalizada, uma vez que o bem jurídico tutelado na esfera penal deverá ser também um indicador constitucional.

Outrossim, reitere-se que o presente trabalho não adentra nos fundamentos envolvendo o desacato na seara penal militar, vez que tal ramo jurídico, ainda que também constitucionalizado e passível de críticas, possui fundamentos e questões outras a serem enfrentadas, como a da disciplina e a da hierarquia. Assim, o trabalho cuida de rechaçar o art. 331 do Código Penal numa visão não apenas dogmática mas como também centrada em elementos da Sociologia e Filosofia.

Nesse diapasão, vê-se que qualquer que seja a posição escolhida, contra ou a favor da criminalização do desacato, há de se vencer o fundamento político e seus problemas gerados, conforme tenta, de maneira muito breve, explicar o último subtópico. Confira-se. 
Fundamento centrado no Direito Constitucional dos Direitos Humanos e no embate com a liberdade de expressão

O novo sistema constitucional, de tez aberta e democrática, possui certos critérios próprios que o coloca distante dos regimes estatais autoritários e ditatoriais, vez que pressupõe que temas como direitos humanos passem a integrar a agenda política dos Estados bem como passem a estar presentes nos textos normativos (a incluir na própria Constituição e em Tratados Internacionais ratificados pelo país), como se tivesse sido uma lição de que "a emergência das sociedades totalitárias está inteiramente vinculada à desconsideração da pessoa humana, enquanto valor fundante, que é, da própria ordem política-jurídica do Estado” (PIOVESAN, 2010, p. 04).

No ponto, foi a partir do processo de redemocratização brasileira que o país passa a fazer parte do sistema interamericano de proteção aos direitos humanos (ilustrado pela OEA, pela Comissão Interamericana de Direitos Humanos e pela Corte Interamericana) e passa a assinalar uma série de tratados versando sobre o tema direitos humanos.

Quanto ao sistema interamericano de proteção aos direitos humanos, vale notar que a própria Comissão de Direitos Humanos e a Corte de Direitos Humanos já têm se deparado com a questão do desacato desde muito tempo, conforme já verificado acima, sendo que em todas as ocasiões estes tem combatido a tipificação do crime de desacato, eis que este não seria compatível com o direito à liberdade de expressão, previsto no artigo 13 da Convenção Americana de Direitos Humanos (conhecida comumente como Pacto de San José da Costa Rica).

Neste ponto, sustenta-se que o Brasil, em sendo parte da Convenção Americana de Direitos Humanos e em tendo em sua própria Constituição dispositivos como os $\$ \$ 2^{\circ}$ e $3^{\circ}$ do artigo $5^{0^{4}}$, não pode esquivar-se e deixar de cumprir os ditames dos direitos humanos. Para além destes dispositivos, a Constituição da República Federativa Brasileira de 1988 também traz a liberdade de expressão como direito de qualquer indivíduo.

Por outro lado, parece ainda vigorar o entendimento maior de que a liberdade de expressão, por não ser um direito absoluto (assim como não é absoluto nenhum direito fundamental, segundo maior parte da doutrina) não autoriza a afronta e descaso para com as autoridades estatais, estando em consonância aos ditames constitucionais (citem-se os seguintes julgados: STF - HC 83.233, RE 801065 AgR/PR, HC 94398/RJ, ADIMC 1969/DF - todos disponíveis no site http://www.stf.jus.br/). Assim, pelo menos aos olhos do Judiciário (em sua grande maioria, com exceções sempre), a alternativa viável partiria apenas de uma mudança legislativa para que o desacato deixe de ser visto como crime.

\footnotetext{
${ }^{4} \$ 2^{\circ}$ do artigo $\left.5^{\circ}\right)$ Os direitos e garantias expressos nesta Constituição não excluem outros decorrentes do regime e dos princípios por ela adotados, ou dos tratados internacionais em que a República Federativa do Brasil seja parte.

$\$ 3^{\circ}$ do artigo $5^{\circ}$ ) Os tratados e convenções internacionais sobre direitos humanos que forem aprovados, em cada Casa do Congresso Nacional, em dois turnos, por três quintos dos votos dos respectivos membros, serão equivalentes às emendas constitucionais. (Incluído pela Emenda Constitucional no 45, de 2004).
} 
Ainda no âmbito do Direito Constitucional dos Direitos Humanos, também há o fundamento jurídico da hierarquia das normas, a qual sugere, seguindo a jurisprudência do próprio STF (notadamente da decisão emanada no RE 466.343/SP, que versava sobre a prisão civil do depositário infiel), que os Tratados Internacionais de Direitos Humanos não seriam meras leis ordinárias, mas, ao revés, teriam força supralegal. Assim, do conflito entre o Código Penal com determinado Tratado Internacional que verse sobre Direitos Humanos, deve prevalecer este Tratado, especialmente em se considerando o critério pro hominne. Deste fundamento, deriva a hipótese de não recepção da norma penal anterior, ou seja, a hipótese de que a Constituição não teria recepcionado o crime de desacato.

De todo modo, ainda que não haja a mudança na legislação penal com a revogação total do desacato, cabível ao Poder Judiciário a figura do controle de convencionalidade. No caso, o desacato iria de encontro das normas propostas pela Convenção Americana de Direitos Humanos, sendo, além de inconstitucional, inconvencional ${ }^{5}$.

Inclusive, cabe citar a recente decisão proferida por Juizado Especial Criminal do Rio de Janeiro, no qual o juízo entendeu pela inconvencionalidade do delito de desacato, com base nos ditames da Convenção Americana de Direitos Humanos e na ideia trazida pela Convenção de Viena dos Direitos dos Tratados (1969), segundo a qual o Estado não poderá alegar disposições de seu direito interno para se eximir do cumprimento de um tratado internacional (EMPORIO DO DIREITO, 2016).

Veja-se que o fundamento ora exarado pode-se dizer um tanto quanto dogmático, que pode ser utilizado de imediato pelo Poder Judiciário, sem a necessidade de se ter um Novo Código Penal em vigor e, inclusive, para o fim de se evitar uma futura responsabilização internacional. Outrossim, o delito de desacato também encontra outras fundamentações para sua não aplicação que não necessariamente se enquadrariam num viés constitucional-legalista, mas que considerariam outros aspectos em torno de um mesmo contexto.

\section{Fundamento centrado no direito à revolução/direito de resistência}

O direito à revolução (também denominado por alguns de direito de resistência) constituir-se-ia em um direito implícito decorrente do regime democrático e que possui como fim maior o confronto com atitudes estatais e como forma de limitação à extensão do Estado contra o indivíduo, consolidando-se por meio da desobediência às leis. Inclusive, "A desobediência civil (...) pode ser encarada como direito humano de primeira geração. Ela é individual quanto ao modo de exercício, quanto ao sujeito passivo do direito e quanto à titularidade" (LAFER, 1999, p. 188).

\footnotetext{
${ }^{5}$ Para saber mais sobre o controle de convencionalidade aplicado ao caso do desacato, vide:
} 
Inclusive, a filosofia e a sociologia tem muito se debruçado sobre o tema, contando com interessantes estudos exarados por autores contemporâneos como Carl Schmitt, Hanna Arendt, Oliveira Vianna, etc.

Seria, pois, um combate do medo imposto pelas autoridades estatais e pela polícia. Um combate, contudo, que é contido pelas autoridades estatais e pela polícia, utilizando aparatos de uma legislação penal já não mais atual. Citando novamente Candido, é como se o Estado conclamasse: "não tenha medo da pobreza, nem do exilio, nem da prisão, nem da morte. Mas tenha medo do medo"(CANDIDO, 1972, p. 05).

Assim, o desacato, como forma de indignação do cidadão para com a autoridade estatal, seria uma das facetas desse direito à revolução. Da mesma forma, seriam facetas a greve, protestos, lutas de movimentos sociais, etc.

Mais especificamente, o tema parece perene de discussões tanto mundo afora quanto em terrae brasilis. Sem adentrar em toda e extensa contextualização frente à forma de criação das Instituições no Brasil, os quais indubitavelmente demonstram uma verticalização exacerbada do Estado sobre seus cidadãos, cumpre apenas clarificar que o direito de resistência pode ser tomado como um fundamento para a não aplicação do delito de desacato.

Por outro lado, teria o fundamento do direito de resistência/direito à revolução semelhança com os demais argumentos na medida em que todos encontram respaldo no sistema constitucional dado a partir do processo de redemocratização, o qual não seria um mero ordenamento jurídico renovado, mas, ao revés, seria um novo sistema, aberto, que impõe um novo pensar e que impõe superar os problemas que a Ditadura Militar ou estados autoritários anteriores deixaram.

O problema maior do argumento do direito de resistência/direito à revolução estaria inscrito na questão da limitação dos direitos fundamentais, ainda mais quando se adota uma teoria restrita como parece adotar o Brasil. Isso porque, pode-se questionar em que medida o direito de resistência/à revolução seria lícito ou permitido e se o desacato (e toda e qualquer hipótese de desacato) não continuaria na seara da ilicitude, na seara das atitudes nãos autorizadas, problema tal que também se coloca na questão do embate do crime de desacato versus liberdade de expressão, eis que sempre se pode incorrer no risco de viver a situação em que "tudo foi dito, sem dúvida. Se as palavras não tivessem mudado de sentido, e os sentidos, de palavras" (HALIMI apud PAULHAN, 2015, trad. livre). Tal fundamento, pois, remonta àquela ideia que vem sendo rebatida ao longo de todo este trabalho: a de que o Estado serve para o povo e deve estar assentado em atitudes democráticas, constitucionais, e não mais assentado em atitudes policialescas.

De toda forma, qualquer que seja os fundamentos jurídicos ora explicitados, nenhum possui a marca da

GONCALVES, A. E. B.; GOMES, E. B.. O Controle de Convencionalidade no Brasil, a Convenção Americana de Direitos Humanos e o Crime de Desacato. Revista Jurídica da Presidência, v. 18, p. 73-96, 2016. 
neutralidade, assim como não a possui a própria definição estatal política, ao que vale verificar que qualquer que seja a posição escolhida, há de se enfrentar o fundamento político que houve por detrás da criminalização do desacato e quais os problemas que este trouxe nos dias atuais.

No plano político: vencer os problemas gerados pelo liberalismo e pelos períodos ditatoriais para poder seguir em frente

Durante todo o trabalho procurou-se demonstrar que legislações penais do Brasil e de seu entorno tinham um cunho político liberal, mas que sobreviveram e foram auxiliares aos períodos ditatoriais e autoritários vivenciados. Ora, se de um lado o liberalismo defendia a bandeira dos direitos fundamentais, a exemplo maior dos direitos de liberdade e de igualdade, com atuação estatal apenas nos casos em que estritamente necessário, por outro lado, de modo perverso aos cidadãos, passou a delinear um estado de legalidade, em que haveria de ser preservado o autoritarismo estatal em detrimento da sociedade civil, reprimida pela via da violência, ilustrada, sobretudo, pela figura dos policiais e do Poder Judiciário.

No entanto, a partir dos processos de redemocratização que ocorreram na América Latina deu-se um novo norte para os sistemas constitucionais, mais voltados à democracia, mas sem deixar de respeitar os direitos fundamentais e humanos garantidos nacional e internacionalmente, o que impõe novos desafios. Para solucionálos e discuti-los, porém, é preciso primeiro vencer os problemas gerados pelas legislações penais de tez liberal, ultrapassando visões autoritárias e violentas, o que também impõe um novo olhar sobre os períodos ditatoriais, "para que não se esqueça, para que nunca mais aconteça", conforme dizeres da Comissão Nacional da Verdade, fruto esta, inclusive, também dos ditames do sistema interamericano de proteção aos direitos humanos, que delimitou pela via da Corte Interamericana, a condenação do Brasil no caso Gomes Lund e outros, conhecido comumente como Guerrilha do Araguaia (CORTE IDH, 2010).

Diante de todo o exposto, remanesce a questão: se o desacato constituir-se-ia uma divergência de todo um novo sistema, até quando continuará a ser aplicado? É o que o último ponto deste artigo pretende verificar.

\section{Fatos portadores de futuro: até quando?}

Atualmente a questão do desacato vem sendo, gradualmente, repensada. No plano do Poder Judiciário Brasileiro, viu-se que os fundamentos acima colocados vêm sendo suscitados por parte da doutrina e da jurisprudência. Viu-se também que a Defensoria Pública do Estado de São Paulo parece ser o mais recente exemplo de um dos atores sociais importantes neste palco, indo ao encontro do entendimento dado pelo sistema interamericano de Direitos Humanos.

Também acompanhando os fundamentos acima estudados, no plano do Poder Legislativo no Brasil já 
há a propositura de projetos de leis que visam a extinção do crime de desacato, a exemplo do PL 602/2015, proposto pelo deputado federal Jean Wyllys e no qual procura extinguir o crime de desacato e, mais, estabelecer o abuso de autoridade como ato de improbidade administrativa, sob os argumentos acima estudados (BRASIL, 2015, p.03). Além disso, há em pauta um projeto de um Novo Código Penal, no qual o delito de desacato não mais integraria o ordenamento jurídico brasileiro. Não obstante, da leitura do Anteprojeto do Novo Código Penal, no Relatório Final da Comissão de Juristas, o delito de desacato seria transformado em injúria qualificada, assim pensado justamente para elidir "a crítica de que existiria um viés autoritário nesta proteção especial ao servidor público, sem deixar, todavia, de manter como crime a ofensa a eles realizada em razão da função" (BRASIL, 2013, p. 367).

Afora do âmbito dos trabalhos realizados por parte do Poder Legislativo, mais recentemente, para se adequar a legislação penal na seara constitucional, já se cogita no âmbito do Ministério Público Federal (MPF) em apresentar futuramente Ação de Descumprimento de Preceito Fundamental (ADPF) na qual pede a inconstitucionalidade do art. 331 do Código Penal, com as fundamentações de incompatibilidade com o sistema interamericano de proteção aos direitos humanos e, inclusive, possibilidade de responsabilização internacional futura (MINISTÉRIO PÚBLICO FEDERAL, 2016).

Por outro lado, tanto sob o ponto de vista do Poder Judiciário quanto sob o ponto de vista das demais funções estatais, ainda são vários os casos de desacato (como os acima suscitados) que chegam diariamente na mesa de juízes e promotores, que ainda parecem entender que é preciso haver uma mudança legislativa para que o desacato deixe de ser visto como crime e que direitos como o da liberdade de expressão, por não serem absolutos, não dão margem aos questionamentos da autoridade estatal.

Assim, não é possível, pelo menos até agora, afirmar de antemão que o crime de desacato vai ser, com toda certeza, extirpado nas legislações penais da América Latina. De qualquer maneira, tem- se que as várias transformações democráticas dos anos 80 que deram força a um novo sistema constitucional parecem demonstrar que a solução não está nas medidas repressivas, ainda que imponham novos desafios, como conciliar a democracia e o Estado com os direitos fundamentais.

\section{CONSIDERAÇÕES FINAIS}

O desacato encontra sua razão de ser na proteção à honra funcional, à honra da autoridade estatal. Nos primórdios, era para proteção da figura do Juiz, mas hoje se volta à proteção de todo e qualquer agente estatal, a exemplo maior da figura policial. Como não há menção legal de quais atitudes seriam desacato, sendo que "da maneira como está hoje, nunca se sabe bem se é crime de desacato ou manifestação de insatisfação" (STJ, 2012).

Apesar de ter sido o desacato fruto de estados autoritários e ditatoriais, hoje vive-se a construção de um 
novo sistema constitucional, aberto e democrático. Assim, a verticalização entre Estado e povo é questionada, bem como são questionadas atitudes policialescas do Estado.

Em face deste novo sistema constitucional e em razão de direitos como o direito à liberdade de expressão, o direito à revolução/direito de resistência, se fala em inconstitucionalidade do crime de desacato. No mesmo sentido, é o posicionamento do sistema interamericano de direitos humanos, que já pediu reiteradas vezes aos países da América Latina para retirarem de seus ordenamentos jurídicos a figura penal do desacato. A Argentina já extinguiu o crime, mas o Brasil, por exemplo, ainda o possui inscrito em seu Código Penal, ao que continua a ser aplicado pelo Poder Judiciário.

Logo, até aqui só é possível afirmar tendências, não se podendo confirmar de prontidão que em pouco tempo o desacato será retirado das legislações penais da América Latina. Apesar disso, cabe o questionamento das leis de desacato e de toda a problemática que a circunda.

\title{
THE CRIME OF DISACACTION AND ITS CORRELATION WITH THE STATE'S REPRESSIVE ATTITUDE
}

\begin{abstract}
This article aims to study the contempt (desacato) crime and what would be its relationship with the attitude "policing" existing in the state, stir authoritarian and dictatorial periods experienced in Brazil and its surroundings. Further, this work advocates the unconstitutionality of the contempt (desacato) in Brazil and its foundations. The problem of this work paper is to undestand the contempt of crime in Brazil and its surroundings, carrying out a situation analysis that takes into account the political and legal factors. In a second step, we try to explain the contempt crime unconstitutional position in Brazil, trying to elucidate the main foundations upon which rests this position. The hypothesis is that the contempt (desacato) crime is a result of a state that values not for his people, but by the authority itself. In other words, it is the contempt (desacato) a result of the dictatorial period and the imposition of a state which is above the people and not vice versa. The justification is that currently, in the light of a new constitutional system is there to speak on unconstitutionality of this criminal offense, however, this position also proposes some challenges. The criminal law is rethinking that certain attitudes are in favor for the benefit of the state and not the people. Thus, appropriate contempt crime study (especially in Brazil) and conducting an analysis of the future. The article has a theoretical-deductive methodology, in which he earned, as a methodological tool, the situation analysis and scenarios.
\end{abstract}

Keywords: Contempt (Desacato); Constitucional System; Inter-American Human Rights System.

\section{REFERENCIAS}

BRASIL, Câmara dos Deputados. Projeto de Lei no 602 de 16 de março de 2015. Disponível em: <http://www.camara.gov.br/proposicoesWeb/fichadetramitacao?idProposicao=964537> Acesso em: 10 jun 
2015. República, 1940.

Código Penal. Decreto-Lei no 2.848, de 7 de dezembro de 1940. Rio de Janeiro: Presidência da

Constituição. Constituição da República Federativa do Brasil. Brasília, DF: Senado, 1988.

Superior Tribunal de Justiça. Notícias do STJ, de 07 de maio de 2012. Disponível em: <http://stj.jus.br/portal_stj/objeto/texto/impressao.wsp?tmp.estilo=\&tmp.area=398\&tmp.texto=105618>. Acesso em: 03 mai 2015.

Senado Federal. Relatório final dos trabalhos da comissão de juristas. Brasília: Senado Federal, 2013, p. 367. Disponível em: <http://www.senado.gov.br/atividade/materia/getPDF.asp?t=110444\&tp=1>. Acesso em: 20 mai 2016.

CANDIDO, Antonio. A verdade da repressão. Jornal Opinião, 1972. Disponível em: $<$ www.revistas.usp.br/discurso/article/download/37854/40581 >. Acesso em: 17 jan 2015.

CORTE IDH. Caso Palamara Iribarne Vs. Chile. Fondo, Reparaciones y Costas. Sentencia de 22 de noviembre de 2005. Serie C No. 135.

Caso Gomes Lund versus Brasil. Sentença de 24 de novembro de 2010. Disponível em <http://www.corteidh.or.cr/docs/casos/articulos/seriec_219_esp.pdf>. Acesso em: 18 de set de 2011.

DEFENSORIA PÚBLICA DO ESTADO DE SÃO PAULO. Pedido de medida cautelar - violação dos artigos 7 (2) e 13 da Convenção Americana sobre Direitos Humanos, 2014. Disponível em: <http://s.conjur.com.br/dl/defensoria-sp-fim-desacato-oea.pdf>. Acesso em: 10 mai 2015.

FALK, Richard. Globalização Predatória: uma crítica. Trad. de Rogério Alves. Lisboa: Instituto Piaget, 1999.

GARAPON, Antoine et alii. Punir em democracia: e a justiça será. Trad. de Jorge Pinheiro. Lisboa: Instituto Piaget, 2001.

HALIMI, Serge. Comment échapper à la confusion politique. Jornal Le Monde Diplomatique, maio 2015.

LAFER, Celso. A reconstrução dos direitos humanos: um diálogo com o pensamento de Hannah Arendt. São Paulo: Companhia das Letras, 1999.

MINISTÉRIO PÚBLICO FEDERAL. PFDC quer inconstitucionalidade do crime de desacato: Procuradoria Federal dos Direitos do Cidadão apresentou ao procurador-geral da República proposta de ADPF sobre o tema. Notícias MPF, 01 de junho de 2016. Disponível em: <http://pfdc.pgr.mpf.mp.br/informativos/edicoes2016/junho/pfdc-quer-inconstitucionalidade-do-crime-de-desacato>. Acesso em: 30 jul 2016.

OEA, Comisión Interamericana de Derechos Humanos. Informe anual de la Comisión Interamericana de Derechos Humanos 998: Informe especial del relator sobre la libertad de expresión 1998. Washington D.C.: Organización de los Estados Americanos, 1999. Relatório.

Informe anual de la Comisión Interamericana de Derechos Humanos 2014. Washington D.C.: Organización de los Estados Americanos, 2015. Relatório.

PAGLIARO, Antonio; DA COSTA JÚNIOR, Paulo José. Dos Crimes Contra a Administração Pública. 2. ed. São Paulo: Malheiros, 1999. 
PIOVESAN, Flávia. Direito humanos e o direito constitucional internacional. - 11.ed. rev. e atual. - São Paulo: Saraiva, 2010.

PRADO, Luiz Regis. Curso de Direito Penal Brasileiro. 6a ed. rev. e atual. São Paulo: Editora Revista dos Tribunais, 2010.

TRINDADE, Antônio Augusto Cançado. A humanização do direito internacional - Belo Horizonte: Del Rey, 2006.

SARLET, Ingo et alii. Curso de Direito Constitucional. São Paulo: Editora Revista dos Tribunais, 2012.

SCHWARTZ, Peter. The Art of the Long View: Planning for the Future in an Uncertain World. New York: Currency Doubleday. 1996.

ZAFFARONI, Eugénio Raúl. BATISTA, Nilo; ALAGIA, Alejandro; SLOKAR, Alejandro. Direito Penal Brasileiro: $1^{\circ}$ volume - Teoria Geral do Direito Penal. $4^{a}$ ed. Rio de Janeiro: Revan, 2011.

Trabalho enviado em 16 de setembro de 2015.

Aceito em 19 de setembro de 2016. 